\title{
Development of Learning Modules in E-Learning-Based Digital Simulation in Class X Students of the Department of Computer Engineering and Networking at Batam Hang Nadim Vocational School
}

\author{
Idham Syafril $^{1}$, Ganefri ${ }^{2}$, Ridwan $^{3}$, B.Herawan Hayadi ${ }^{4}$, Almadison $^{5}$ \\ Master of Technology and Vocational Education Masters Program, Faculty of Engineering, \\ Padang State University ${ }^{1,2,3}$ \\ University of Pasir Pengaraian, Riau Indonesia ${ }^{4,5}$ \\ \{idham.syafril@gmail.com $\left.{ }^{1}\right\}$
}

\begin{abstract}
Based on observations, the problems that exist are the limitations of the teacher in delivering the material using textbooks and lecture methods and explaining on the board, so that the material requires a clear module. The purpose of this study is to produce a valid, practical and effective E-Learning based digital simulation module. The method used is Research and Development with the ADDIE development model. The research subjects were Class $\mathrm{X}$ students at Hang Nadim Batam who took digital simulation subjects. Types of data are primary data where data is provided by teachers and students. The instrument for collecting data is in the form of a questionnaire. Descriptive data analysis technique is to describe the validity, practicality, and effectiveness of digital simulation modules. The results obtained from this development research are as follows: (1) Producing a digital simulation module, (2) The validity of the digital simulation module is declared valid in the aspects of content (format) and presentation aspects, (3) The practicality of digital simulation modules based on teacher responses is stated to be very practical and based on student responses, 4) The effectiveness of digital simulation modules is declared effective to improve student learning outcomes seen from the number of students who graduate in learning. Based on the findings of this study it was concluded that this digital simulation module is valid, practical and effective to be used as a learning module on digital simulation subjects.
\end{abstract}

Keywords: Lecture Methods, E-Learning, ADDIE development model

\section{Introduction}

In the Vocational Education Unit Level Curriculum (2004 CBC and 2006 Content Standards)[1] it is emphasized that: The purpose of Vocational Secondary Education is to improve intelligence, knowledge, personality, noble character, and skills to live independently and follow further education in accordance with their vocational, or include four competencies, namely (1) spiritual attitude competence, (2) social attitudes, (3) knowledge, and (4) skills. 
This competency is achieved through intra-curricular, curricular, and extracurricular learning processes. The formulation of the spiritual attitude competency, namely, "Accepting and carrying out the teachings of the religion he adheres to." Whereas the formulation of social attitude competencies is, "Living and practicing honest behavior, discipline, responsibility, caring (mutual cooperation, cooperation, tolerance, peace), courtesy, responsiveness and proactivity and showing attitude as part of the solution to various problems in interacting effective with the social and natural environment, and can position themselves as a reflection of the nation in world relations" [2]-[4].

E-learning or electronic learning is a concept of learning carried out through electronic media networks [5], [6]. The development of highly advanced technology in the modern era and globalization allows various activities to be carried out quickly and efficiently. The development of technology has had a lot of influence on our way of life, one of which is in the field of education with the use of e-learning in learning activities in schools, colleges, places of study and even online communities have begun to use concepts like this. Along with the development of information technology and the demands of the globalization of education and distance learning, various concepts have been developed to replace traditional learning methods, one of which is the concept of e-learning. E-learning can be used as an alternative to problems in the field of education, both as additional, complementary and substitute for existing learning activities[7].

In connection with the implementation of the teaching and learning process, in the Government Regulation of the Republic of Indonesia No.19 of 2005 concerning National Standards of Education in educational units held in an interactive, inspirational, fun, challenging, motivating students to participate actively. Based on the results of observations conducted at Hang Nadin Vocational School in Batam that have implemented the 2013 curriculum, the teacher admitted that it was difficult to invite students to be active in learning in Digital Simulation material. Educators/teachers feel that teacher, and student handbooks have not provided convenience in learning so that learning runs interactively, inspirationally, pleasantly. Therefore, there is a need for a Module that can enrich the material about Digital Simulation, where the grade $\mathrm{X}$ of vocational school students are for the first time to recognize Digital Simulation. Changes in the mindset of junior high school students who have never known the basics of digital simulation pose problems. As stated by the Digital Simulation subject teacher, the difficulty faced is to invite active students.

The learning activities of the teaching staff/teachers have used textbooks, but there are still many student learning outcomes under the KKM (Minimum Completion Criteria). This can be seen in the learning outcomes of students of class X of Computer Engineering and Networks listed in Table 1:

Table 1. Data on Student Learning Outcomes in Digital Simulation Courses Class X of Computer and Network Engineering in the academic year of 2017/2018

\begin{tabular}{|c|c|c|c|c|c|c|}
\hline \multirow{3}{*}{ No } & \multirow{3}{*}{ Class } & \multirow{3}{*}{$\begin{array}{l}\text { Total of } \\
\text { students }\end{array}$} & \multicolumn{4}{|c|}{ Minimum Completion Criteria } \\
\hline & & & \multicolumn{2}{|c|}{ Value $<75$} & \multicolumn{2}{|c|}{ Value $\geq 75$} \\
\hline & & & Total & Percentage & Total & Percentage \\
\hline 1 & X TKJ 1 & 28 & 15 & $53.6 \%$ & 13 & $46.4 \%$ \\
\hline 2 & $\mathrm{X}$ TKJ 1 & 28 & 14 & $50.0 \%$ & 14 & $50.0 \%$ \\
\hline & TOTAL & 56 & 29 & $51.8 \%$ & 27 & $48.2 \%$ \\
\hline
\end{tabular}


Source: Teacher of Digital Simulation Subject of Hang Nadim Vocational High School in Batam

From the description above, it can be seen that the value of learning outcomes of Digital Simulation is still much below the standard Minimum Completion Criteria (KKM) which is set at 7.50. From the data on completeness of learning outcomes, there are many factors that make student learning outcomes not meet the Minimum Completion Criteria standard, including:

1. Limitations of teacher competency about the material being taught.

2. Lack of teacher interest to carry out interactive learning with students.

3. Low interest and motivation from students in the learning process, especially Digital Simulation subjects

\section{Method}

This type of research is a type of Research and Development (R \& D) research that aims to 1) develop learning modules on class $X$ of Digital Simulation subjects at Batam Hang Nadim Vocational School, 2) produce new products (modules) in the learning system. According to Sugiyono (2013) Research and development method (R \& D) is a method of research that products from the results of research if used to help do work, the work will be more productive, effective and efficient.[8]

The development model used is the ADDIE model. This ADDIE model was chosen for the following reasons.

1. This model is very simple when compared to other models.

2. This model is easy to learn.

3. Systematic structure from the first stage to the fifth stage.

4. It cannot be sorted randomly because it has the characteristics of a procedural model.

The researcher did not choose other models; for example, the 4D model because the researcher did not arrive at the disseminated stage. The Borg and Gall model, in addition to the complicated steps (10 steps), this model also has stages of disseminating, namely in step 10 .

\section{Result and discussion}

\subsection{Digital Simulation Learning Module}

Digital simulation subjects are carried out in theoretical and practical forms so that they can be used as student capital after graduating later. Noting the characteristics of the learning process especially digital simulation that is unique and comprehensive, the development of digital simulation modules is potential enough to meet the demands of this learning. The advantages of digital simulation modules are supporting existing teaching materials, giving students the opportunity to learn independently[9].

The process of developing this learning module is carried out in 5 stages, namely as in the development model used is the ADDIE development model consisting of 5 main stages, namely, analysis, design, develop, and evaluate.

In the analysis phase, several activities were carried out, namely curriculum analysis and material analysis. This stage is carried out as a basis for developing digital simulation modules on digital simulation subjects so that they can be used to facilitate students' self-learning. After 
conducting the analysis phase, a digital simulation module was obtained which presented three learning topics[10].

After the digital simulation module has been developed, the validity, practicality, and effectiveness of the module are then tested. By what was stated by Endrya (2010: 34) that "a teaching material developed, can only be used in learning must first pass the test of validity, practicality, and effectiveness."

\subsection{The validity of Digital Simulation Learning Modules}

Based on the results of the research that has been done, the validated digital simulation learning module fulfills the requirements of a good module, namely compiling module components according to indicators, conformity of content in the learning module, clarity of instructions, preparation of material in the learning module, conformity of formats, display and language in the learning module making it easier for students to understand digital simulation learning and be able to apply it.

According to Trianto [11], Valid means that it has provided accurate information about teaching materials developed. Validation of the digital simulation learning module on digital simulation subjects was carried out by a validator consisting of three experts/experts. The three validators are experts in the field of study; therefore the results of this validation can be justified. The digital simulation learning module developed has fulfilled the Content aspect of the digital simulation learning module is Valid with the Aiken's V value of 0.897 . The format aspect of the digital simulation learning module is Valid with the Aiken's V value of 0.864 . The presentation aspect of the digital simulation learning module is Valid with Aiken's V value of 0.883 . These three aspects, if added to the score of the validity value obtained from each validator, obtained Aiken's V with an average of 0.881 . The value obtained is in the valid category.

In the module content, the validator states that the digital simulation learning module developed as one of the learning media is in accordance with the curriculum, and the learning objectives that must be achieved by students, including the suitability of module content, clarity of instructions, compilation of material, conformity between the material practiced with the media learning, the suitability of the image with the material that is practiced, the display of images and writing so that it makes it easier for students to understand the learning material. The value of the validation of the contents of the digital simulation learning module developed is 0.897 with a valid category. Content validation is a condition relating to the process of finding concepts that are true and by the applicable curriculum. Valid validation results for content validation indicate that the digital simulation learning module developed has been very by the curriculum currently in use.

In the format aspect, the validation value of the validator also obtains a valid value which is 0.864 categorized as valid. The validity of the module format is the suitability of the module components with the elements that have been defined. Based on the value of the validity obtained from the validator, it can be concluded that the digital simulation learning module developed is by the construction requirements of the learning module. Presentation validity is an indicator of validity about the use of language, writing, images, and appearance in making digital simulation learning modules. The validation value of presenting a digital simulation learning module is 0.883 with a valid category. So, the presentation validation also gets a valid value. This indicates that the digital simulation learning module developed has been very much by the technical requirements of a learning module. 


\subsection{The practicality of Digital Simulation Learning Modules}

Practical testing of digital simulation learning modules is carried out by teachers and students through teacher and student response questionnaires. Teacher questionnaire responses were given to 2 teachers to see the teacher's response in the practicality of using digital simulation learning modules. Questionnaire for student responses was given to 20 students to see the practicality of using this digital simulation learning module.

The results of module practicality tests by teachers with an average percentage were $87.50 \%$ with a very practical category. These results indicate that the digital simulation module developed facilitates teachers in helping students learn independently and helps teachers to understand the concepts of learning material. Practicality of digital simulation modules based on student responses with an average percentage of 81.63 with a very practical category. These results indicate that the very practical categories developed can facilitate students in understanding the material.

The practical module means making it easier for students to understand digital simulation learning. Susilana and Riyana, (2008: 03) revealed that "the good and bad of learning is supported by users of learning media." Modules can make the learning atmosphere fun because students are more motivated to complete learning to see what products they can later produce.

\subsection{The effectiveness of Digital Simulation Learning Modules}

The effectiveness of the module in this study is seen from the module's ability to activate students in learning and facilitate understanding the learning material. According to Oemar Hamalik [12], "the use of teaching materials will greatly help the effectiveness of the learning process and the delivery of messages at the time." In addition to increasing the activity of teaching materials can also help students improve their understanding. In this assessment, the effectiveness of teaching materials in the form of modules is reviewed in terms of student learning outcomes.

Learning outcomes tests are used to determine the effectiveness of the learning process. Learning outcomes are abilities that students have after they go through the process of the learning experience. Learning experiences in the form of effective learning activities and can realize good learning outcomes. The purpose of the assessment of learning outcomes is to measure the level of success of the teaching and learning process that has been carried out.

From this description shows that the use of digital simulation modules developed makes it easier for students to understand the material so that student learning outcomes become better. Like what was stated by Harun Rasyid and Mansur [13] "evaluation is the process of determining the extent to which the learning process has been achieved." Based on the results of learning for digital simulation learning, it shows that of the 20 students who took the test before they used the digital simulation module had an average learning outcome of 62 , with the category quite effective.

Based on learning outcomes data from 20 students who took the test after they used digital simulation modules had an average learning outcome of 82 ; this includes a very effective category. This shows that there is an increase in student learning outcomes before using the module after using a digital simulation module. So, it can be concluded that learning using modules can be said to be effective in improving student learning outcomes. 


\section{Conclusion and suggestion}

Based on the results of module development research that has been done, the following conclusions are obtained:

1. Research on the development of digital simulation learning modules is developed using the ADDIE model, which consists of the analysis, design, develop and evaluate stages. The digital simulation learning module consists of 3 topics, namely the first topic about logic, the second topic about mind maps, and the third topic about descriptive paragraphs, argumentative, narrative and persuasive.

2. The validity of the digital simulation learning module developed has met the aspects of content (format), aspects of the format, and aspects of the presentation of digital simulation learning modules. So it can be concluded that the digital simulation learning module developed is valid for use in learning.

3. Module practicality in learning can be seen from the good implementation of the use of digital simulation learning modules. This can be seen from the results of the response of teachers and students who showed that the digital simulation learning modules developed included in the very practical category.

4. The effectiveness of modules developed on students seen from the learning outcomes of students who take the test before using the digital simulation learning module with after using product-based modules shows that there is an increase in learning outcomes. So, it can be concluded that learning using modules can be said to be effective in improving student learning outcomes.

Based on the research conducted, the following matters are suggested.

1. It is recommended for teachers to be able to use the digital simulation learning module as a learning support media, to support the improvement of student learning outcomes.

2. Suggested For students, after using the digital simulation learning module, it is expected to be more active to encourage self-potential in improving learning outcomes.

3. It is recommended to other researchers to develop things related to learning media, both in digital simulation subjects and other subjects.

\section{References}

[1] C. Chen, "Developing the Digital Materials for Solar Energy Technology in Daily Life," 2012 8th Int. Conf. Inf. Sci. Digit. Content Technol., vol. 2, pp. 306-312.

[2] M. Chua, F. W. Olin, T. Edmonds, and F. W. Olin, "Curricular culture literacy and miscodes in its absence: making sense of conflicts in cross- institutional curricular collaborations," 2017.

[3] W. Chung, "Developing Curricular Modules for Cybersecurity Informatics: An Active Learning Approach,” pp. 164-166, 2017.

[4] T. Edmonds, F. W. Olin, M. Chua, and F. W. Olin, "Aspects that influence curricular change capacity: characterizing the transferability, openness, and literacy of individual changemakers," 2017.

[5] Y. Ping, W. Yanni, L. I. Jinping, and K. Bo, "Study on personality learning in Elearning," 2009 Int. Conf. E-Learning, E-Business, Enterp. Inf. Syst. E-Government, pp. 126-128, 2009.

[6] Z. Asma and B. Tahar, "Hybrid Approach for Modeling Units of Learning," Int. Conf. Educ. e-Learning Innov., pp. 1-3, 2012. 
[7] S. S Shmed, "The Role of e-Learning to Face the Challenges of the Century . 2013 Fourth Int. Conf. e-Learning "Best Pract. Manag. Des. Dev. e-Courses Stand. Excell. Creat., p. 275, 2013.

[8] J. G. Martel, "Research and development by electric utilities in Canada," 2006 IEEE Power Eng. Soc. Gen. Meet., p. 1 pp., 2006.

[9] T. Dong, Y. Zhang, G. Li, and B. Li, "The Research and Development of Parts Library System oriented to High Voltage Switchgear," pp. 2-6, 2009.

[10] D. Puyada, G. Ganefri, A. Ambiyar, R. E. Wulansari, and B. Herawan Hayadi, "Effectiveness of interactive instructional media on Electrical Circuits," Int. J. Eng. Technol., vol. 7, no. 2.14 Special Issue 14, 2018. 